SULTANIST: Jurnal Manajemen dan Keuangan Volume: 7 No: 2 Tahun 2019 Page (32-42)

ISSN: 2338-4328 (Print), ISSN: 2686-2646 (Online)

Available online at: https://sultanist.ac.id/index.php/sultanist

\title{
PENGARUH LIKUIDITAS TERHADAP NILAI PERUSAHAAN DENGAN LEVERAGE SEBAGAI VARIABEL INTERVENING PADA PT UNILEVER, TbK YANG TERDAFTAR DI BURSA EFEK INDONESIA
}

Jody Styawan ${ }^{1}$, Robert Tua Siregar ${ }^{2}$, Sherly $^{3}$, Novita Butarbutar ${ }^{4}$

Program Studi Manajemen, Sekolah Tinggi Ilmu Ekonomi Sultan Agung, Jchen9597@gmail.com

Program Studi Manajemen, Sekolah Tinggi Ilmu Ekonomi Sultan Agung, tuasir@stiesultanagung.ac.id, sherly@ stiesultanagung.ac.id, novita@stiesultanagung.ac.id

\begin{abstract}
Abstrak
Adapun rumusan masalah penelitian ini adalah bagaimana pengaruh likuiditas terhadap leverage dan pengaruh leverage terhadap nilai perusahaan pada PT Unilever, Tbk yang terdaftar di Bursa Efek Indonesia. Penelitian ini menggunakan desain penelitian kepustakaan. Data yang digunakan adalah data sekunder yang diperoleh dari idx.co.id. Kemudian teknik analisa data menggunakan metode deskriptif kualitatif dan metode deskriptif kuantitatif. Hasil analisis dari regresi linier sederhana (1) yaitu $\mathrm{Z}=4,736-3,796$ Xartinya likuiditas berpengaruh negatif terhadap leverage. Sedangkan hasil regresi linear sederhana (2) yaitu $\hat{Y}=13,952+13,533 \mathrm{Z}$ artinya leverage berpengaruh positif terhadap nilai perusahaan. Hubungan korelasi (1) adalah sangat kuat yaitu $r=0,917$ sedangkan koefisien determinasi (1) dapat dijelaskan baik buruknya likuiditas $84,0 \%$, dan sisanya $16,0 \%$ dijelaskan oleh faktor lainnya yang tidak dibahas dalam penelitian ini. Hubungan korelasi (2) adalah kuat yaitu r $=0,769$ sedangkan koefisien determinasi (2) dapat dijelaskan baik buruknya leverage $59,1 \%$ dan sisanya $40,9 \%$ dijelaskan oleh faktor lainnya yang tidak dibahas dalam penelitian ini. Dari hasil pengolahan dan perhitungan data sekunder, penulis mendapatkan kesimpulan bahwalikuiditas pada PT Unilever, Tbk berpengaruh negatif dan signifikan terhadap leverage sedangkan leverage pada PT Unilever, Tbk berpengaruh positif dan signifikan terhadap nilai perusahaan.
\end{abstract}

Kata Kunci : Likuiditas, Leverage, Nilai Perusahaan

\section{THE INFLUENCE OF LIQUIDITY ON CORPORATE VALUES WITH LEVERAGE AS INTERVENING VARIABLES IN PT UNILEVER, TbK LISTED IN INDONESIA STOCK EXCHANGE}

Abstract

The formulation of the problem of this research is how the effect of liquidity on leverage and the effect of leverage on the value of the company at PT Unilever, Tbk, which is listed on the Indonesia Stock Exchange. This study uses a library research design. The data used are secondary data obtained from idx.co.id. Then the data analysis technique uses descriptive qualitative methods and quantitative descriptive methods. The result of this study can be summarized as follows: 1. liquidity, leverage, and firm value are good. 2. The results of the first simple linier regression is $Z=4,736-3,796 X$ it means liquidity has a negative influence on leverage. While the results of the second simple linier regression is $\hat{Y}=13,952+13,633 Z$ it means leverage has a positive influence on firm value.3. The results of the first correlation coefficient analysis is 0,917 which means a moderactly high relationship between liquidity with leverage. The first coefficient of determination is 0,840 which means that $84,0 \%$ of leverage is explained by liquidity. The second correlation coefficient analysis is 0,769 which means high relationship between leverage with firm value. The coefficient of determination is 0,591 which means that $59,1 \%$ of firm value is explained by leverage.4. The first $H_{0}$ hypothesis research is rejected, meaning that liquidity has a negative significant effect to leverage. While the second $H_{0}$ hypothesis research is rejected, meaning that leverage has a positive significant effect to firm value.

Keywords: Liquidity, Leverage, Firm Value 



\section{PENDAHULUAN}

Unilever merupakan salah satu perusahaan yang go public dengan ruang kegiatan perusahaan di bidang makanan dan minuman. Bagi perusahaan yang go public, keunggulan kompetitif harus dikembangkan dan hal ini menuntut perusahaan untuk berupaya menciptakan peningkatan kinerja keuangannya. Untuk mengukur kinerja keuangan tersebut, perusahaan perlu menggunakan rasio keuangan. Selain itu, memaksimalkan nilai perusahaan dinilai lebih tepat sebagai tujuan perusahaan karena menjadi salah satu penilaian bagi para investor tentang kinerja perusahaan saat ini maupun untuk periode di masa yang akan datang.

Salah satu pendekatan untuk mengukur nilai perusahaan melalui rasio nilai pasar adalah nilai pasar terhadap nilai buku (Price to Earning Ratio atau PER), yang memberikan indikasi bagaimana investor menilai ataupun mengukur keberhasilan suatu perusahaan karena dengan meningkatkan nilai perusahaan maka kemakmuran pemilik perusahaan dan pemegang saham juga akan turut meningkat juga. Leverage merupakan rasio yang mengukur seberapa banyak perusahaan menggunakan dana dari hutang (pinjaman). Namun, penggunaan utang yang terlalu berlebihan dapat membuat perusahaan tidak stabil dan tidak dapat mempertahankan kelangsungan hidup perusahaan. Manajemen Hutang atau Leverage merupakan faktor yang juga dapat mempengaruhi nilai perusahaan. Rasio leverage yang digunakan dalam melakukan penelitian ini adalah Debt to Equity Ratio (DER).

Likuiditas merupakan salah satu rasio yang menggambarkan kemampuan perusahaan untuk memenuhi kewajiban (hutang) keuangan jangka pendek. Dalam penilaian terhadap tingkat likuiditas sebuah perusahaan merupakan salah satu cara untuk menilai apakah perusahaan tersebut dalam kondisi sehat atau tidak sehat. Dalam penelitian ini rasio likuiditas yang digunakan adalah Current Ratio (CR).
Berikut ini adalah data mengenai Current Ratio (CR), Debt to Equity Ratio (DER) dan Price to Earning Ratio (PER) pada PT Unilever, Tbk yang terdaftar di Bursa Efek Indonesia periode 2009-2017.

Tabel 1. Current Ratio, Debt to Equity

Ratio dan Price to Earning Ratio pada PT Unilever, Tbk yang terdaftar di Bursa Efek Indonesia Periode 2009-2017

\begin{tabular}{|c|c|c|c|}
\hline Tahun & Likuiditas & Leverage & $\begin{array}{c}\text { Nilai } \\
\text { Perusahan }\end{array}$ \\
\cline { 2 - 4 } & CR (kali) & $\begin{array}{c}\text { DER } \\
\text { (kali) }\end{array}$ & PER (kali) \\
\hline 2009 & 1,04 & 1,02 & 27,69 \\
\hline 2010 & 0,85 & 1,15 & 37,16 \\
\hline 2011 & 0,69 & 1,85 & 34,43 \\
\hline 2012 & 0,67 & 2,02 & 32,89 \\
\hline 2013 & 0,70 & 2,14 & 37,09 \\
\hline 2014 & 0,71 & 2,11 & 42,95 \\
\hline 2015 & 0,65 & 2,26 & 48,30 \\
\hline 2016 & 0,61 & 2,56 & 46,30 \\
\hline 2017 & 0,63 & 2,65 & 60,89 \\
\hline
\end{tabular}

Sumber: Data Diolah (2019)

Pada tabel 1 dapat dilihat bahwa likuiditas yang dihitung dengan Current Ratio (CR) pada tahun 2009 sampai dengan tahun 2017 mengalami fluktuasi setiap tahunnya dan cenderung menurun. Akan tetapi leverage dihitung dengan DER Semakin tinggi. Leverage yang dihitung dengan Debt to Equity Ratio (DER) pada tahun 2009 sampai dengan tahun 2017 mengalami peningkatan akan tetapi pada tahun 2012 leverage naik menyebabkan nilai perusahaan menurun dan pada tahun 2014 leverage menurun menyebabkan nilai perusahaan mengalami kenaikan.

Tujuan penelitian adalah untuk mengetahui gambaran likuiditas, leverage dan nilai perusahaan pada PT Unilever, Tbk yang terdaftar di Bursa Efek Indonesia. Untuk mengetahui pengaruh likuiditas terhadap leverage perusahaan pada PT Unilever, Tbk yang terdaftar di Bursa Efek Indonesia. Untuk mengetahui pengaruh leverage terhadap nilai perusahaan perusahaan pada PT Unilever, Tbk yang terdaftar di Bursa Efek Indonesia. 


\section{LANDASAN TEORI}

\section{Manajemen dan Manajemen Keuangan}

Implementasi kinerja keuangan perusahaan sangat bergantung pada proses kelancaran dan konsistensi manajemen perusahaan. Menurut Robbins dan Mary (2010), menyatakan bahwa manajemen adalah proses mengarahkan dan mengelola orang-orang dengan berbagai latar belakang yang berbeda-beda dengan tujuan yang diinginkan. Salah satu bidang manajemen fungsional perusahaan yang berhubungan dengan pengambilan keputusan investasi jangka panjang, keputusan pendanaan jangka panjang dan pengelolaan modal kerja perusahaan yang meliputi investasi dan pendanaan jangka pendek (Sudana, 2011).

\section{Likuiditas}

Keadaan perusahaan yang baik dalam mengelola sumber daya internal maupun eksternal salah satunya ditunjukkan dengan pengelolaan likuiditas yang efektif. Menurut Sudana (2011:21), "rasio likuiditas yaitu rasio yang mengukur kemampuan perusahaan untuk memenuhi kewajiban keuangan jangka pendek." Likuiditas mengacu kepada kemampuan perusahaan untuk memenuhi kewajiban jangka pendeknya.

\section{Leverage}

Kondisi biaya operasional yang terus meningkat dalam perusahaan perlu dicermati agar tidak membebani tujuan perusahaan sehingga perlu strategi pengukuran rasio yang tepat yang disebut dengan rasio leverage. Menurut Kasmir (2010:112), leverage ratio merupakan rasio yang dipakai untuk menilai sejauh mana aktiva perusahaan dibiayai menggunakan hutang.

\section{Nilai Perusahaan}

Hubungan harga sahan perusahaan pada umumnya memiliki relevansi dengan laba perusahaan. Menurut Keown, et. al. (2004:470), "nilai perusahaan adalah nilai pasar terhadap surat berharga hutang atas ekuitas perusahaan yang beredar.Bagi pemegang saham, harga pasar saham perusahaan menggambarkan nilai perusahaan termasuk seluruh kompleksitas dan risiko dunia nyata.

\section{Pengaruh Likuditas Terhadap Leverage}

Perusahaan harus memiliki tingkat ketersediaan jumlah kas yang baik atau aset lainnya yang dapat diubah menjadi kas. Representatif kemampuan perusahaan dalam membayar utang lancar salah satunya dengan menggunakan aset lancar yang dimiliki (Sudana, 2011). Hal ini sejalan dengan penelitian yang dilakukan Widjaja (2014) yang menyatakan terdapat pengaruh antara likuiditas terhadap leverage.

\section{Pengaruh Leverage Terhadap Nilai Perusahaan}

Meningkatnya nilai perusahaan menunjukkan bahwa semakin sejahtera pemilik perusahaan atau pemegang saham. Faktor leverage memiliki peran yang krusial dalam mengelola hutang sehingga keuntungan yang diperoleh mampu menutupi hutang. Menurut Brigham dan Joel (2010), kenaikan tingkat utang akan berdampak biaya ekuitas sehingga terjadi penurunan harga saham. Hal ini sejalan dengan penelitian yang dilakukan Sambora, Siti dan Sri (2014), Hasibuan, Moch dan Endang (2016), Solikahan, Kusuma dan Achmad (2013), Sholekah dan Lintang (2014), Ramadhani, Akhmadi dan Kuswantoro (2018), Suwardika dan I Ketut (2017), Rudangga dan Gede (2016) yang menyatakan bahwa terdapat pengaruh antara leverage terhadap nilai perusahaan. 


\section{METODE PENELITIAN}

Desain penelitian merupakan suatu cara yang sistematis dan objektif dengan maksud untuk memperoleh data atau mengumpulkan keterangan untuk diteliti. Adapun desain penelitian yag digunakan dalam penulisan skripsi ini adalah penelitian kepustakaan (library research). Teknik pengumpulan data yang berupa dokumentasi. Adapun jenis data yang digunakan dalam penelitian ini adalah data kualitatif dan kuantitatif. Hasil data yang diperoleh akan dianalisis secara deskriptif baik bersifat kualitatif dan kuantitatif.

\section{PEMBAHASAN}

\section{Analisis Deskriptif Kualitatif}

Metode deskriptif kualitatif merupakan metode analisis yang bertujuan untuk mengetahui gambaran atau deskripsi mengenai likuiditas, leverage dan nilai perusahaan pada PT Unilever, Tbk yang terdaftar di Bursa Efek Indonesia. Adapun penetapan parameter dan skala yang dipakai dalam penelitian ini adalah sebagai berikut:

Tabel 2. Penetapan Parameter dan Skala

\begin{tabular}{|c|l|l|l|}
\hline No & Variabel & Parameter & Skala \\
\hline 1. & $\begin{array}{l}\text { Likuiditas } \\
(\mathrm{X})\end{array}$ & $\begin{array}{l}\text { Current Ratio= } \\
\text { Aset Lancar } \\
\text { Hutang Lancar }\end{array}$ & Rasio \\
\hline 2. & $\begin{array}{l}\text { Leverage } \\
(\mathrm{Z})\end{array}$ & $\begin{array}{l}\text { Debt to Equity Ratio= } \\
\text { Total Debt }\end{array}$ & Rasio \\
\hline 3. & $\begin{array}{l}\text { Nilai } \\
\text { Perusahaan } \\
(Y)\end{array}$ & $\begin{array}{l}\text { Price to Earning } \\
\text { Ratio }= \\
\text { Market Price per Share }\end{array}$ & Rasio \\
\hline Earning per Share & \\
\hline
\end{tabular}

Sumber: hasil pengolahan data (2019)

Gambaran Likuiditas pada PT Unilever, Tbk yang terdaftar di Bursa Efek Indonesia Periode 2009-2017

Likuiditas sebagai salah satu rasio yang dgunakan untuk mengukur kemampuan perusahaan untuk memenuhi kewajiban jangka pendeknya dengan aset lancar yang dimiliki perusahaan. Dalam penelitian ini, penulis menggunakan Curent Ratio (CR) sebagai parameter untuk menggambarkan bagaimana kondisi likuiditas pada PT Unilever, Tbk. Current Ratio (CR) adalah rasio yang membandingkan total aset lancar yang dimiliki dengan total hutang lancar. Berikut ini adalah data Current Ratio (CR) pada PT Unilever, Tbk periode 2009-2017 yang disajikan pada tabel:

Tabel 3. Current Ratio pada PT Unilever, Tbk yang terdaftar di Bursa Efek Indonesia Periode 2009-2017

\begin{tabular}{|l|l|l|l|}
\hline Tahun & $\begin{array}{l}\text { Aset Lancar } \\
(\mathbf{R p})\end{array}$ & $\begin{array}{l}\text { Hutang Lancar } \\
(\mathbf{R p})\end{array}$ & $\begin{array}{l}\text { Current } \\
\text { Ratio } \\
(\mathbf{C R}) \\
(\text { Kali })\end{array}$ \\
\hline 2009 & 3.598 .793 .000 .000 & 3.454 .869 .000 .000 & 1,04 \\
\hline 2010 & 3.748 .130 .000 .000 & 4.402 .940 .000 .000 & 0,85 \\
\hline 2011 & 4.446 .219 .000 .000 & 6.474 .594 .000 .000 & 0,69 \\
\hline 2012 & 5.035 .962 .000 .000 & 7.535 .896 .000 .000 & 0,67 \\
\hline 2013 & 5.862 .939 .000 .000 & 8.419 .442 .000 .000 & 0,70 \\
\hline 2014 & 6.337 .170 .000 .000 & 8.864 .832 .000 .000 & 0,71 \\
\hline 2015 & 6.623 .114 .000 .000 & 10.127 .542 .000 .000 & 0,65 \\
\hline 2016 & 6.588 .109 .000 .000 & 10.878 .074 .000 .000 & 0,61 \\
\hline 2017 & 7.941 .635 .000 .000 & 12.532 .304 .000 .000 & 0,63 \\
\hline Rata-Rata & 0,73 \\
\hline \multicolumn{3}{|l}{ Nilai Minimum } & 0,61 \\
\hline Nilai Maksimum & 1,04 \\
\hline
\end{tabular}

Sumber: Laporan Keuangan PT Unilever, Tbk (Data Diolah, 2019)

Berdasarkan tabel 3 dapat dilihat ratarata Current Ratio (CR) pada PT Unilever, Tbk periode 2009-2017 juga bisa disajikan dalam bentuk grafik pada gambar 1 yakni sebagai berikut:

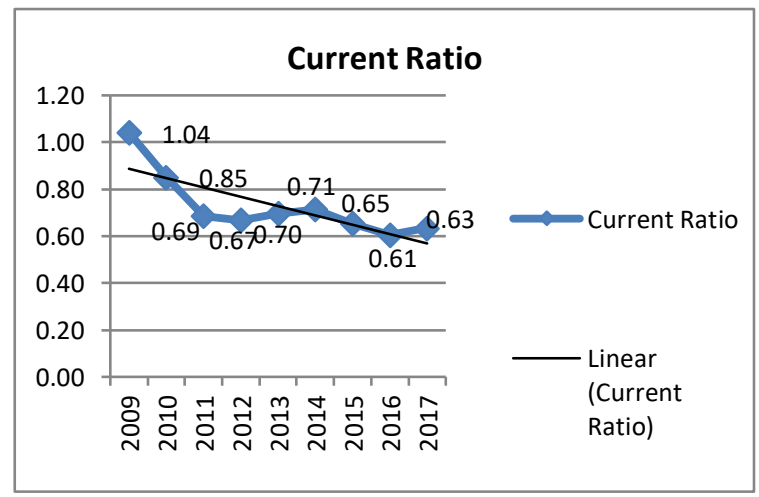

Sumber: Data Diolah (2019)

Gambar 1. Grafik Current Ratio pada PT Unilever, Tbk yang terdaftar di Bursa Efek Indonesia Periode 2009-2017 
Pada tabel 3 dan gambar 1 dapat dilihat bahwa nilai Current Ratio (CR) pada PT Unilever, Tbk yang terdaftar di Bursa Efek Indonesia berfluktuasi dan cenderung menurun. Hal ini diketahui nilai Current Ratio (CR) minimum perusahaan periode 2009-2017 yakni sebesar 0,61 kali pada tahun 2016, yang disebabkan oleh hutang lancar meningkat lebih tinggi dibandingkan dengan peningkatan aset lancar perusahaan tahun bersangkutan yang artinya setiap hutang lancar sebesar Rp.1,00 dijamin oleh aset lancar sebesar Rp.0,61. Nilai Current Ratio (CR) maksimum perusahaan pada periode 2009-2017 adalah sebesar 1,04 kali pada tahun 2009. Hal ini dikarenakan aset lancar yang dimiliki oleh perusahaan lebih besar dibandingkan hutang lancar ataupun terjadi peningkatan aset lancar dari tahun 2008 ke tahun 2009 sebesar Rp.495.498.000.000. Aset lancar yang mengalami peningkatan pada tahun 2009 adalah kas dan setara kas, piutang usaha dan persediaan dengan proporsi 23,85\%, $34,95 \%$, dan $37,23 \%$ sehingga setiap Rp.1,00 hutang lancar dijamin oleh aset lancar sebesar Rp.1,04. Nilai rata-rata Current Ratio (CR) perusahaan adalah sebesar 0,73 kali, yang artinya setiap Rp.1,00 aset lancar dapat memenuhi hutang lancar sebesar Rp.0,73.

Gambaran leverage pada PT Unilever, Tbk yang terdaftar di Bursa Efek Indonesia Periode 2009-2017

Leverage merupakan rasio yang mengukur tingkat seberapa besar perusahaan dibiayai oleh hutang ataupun kewajiban jangka panjang dimana semakin tinggi tingkat leverage sebuah perusahaan maka semakin tinggi juga risiko yang dihadapi oleh perusahaan. Hutang jangka panjang dapat digunakan untuk menambah ekuitas yang dimiliki oleh perusahaan. Dalam penelitian ini penulis menggunakan parameter Debt to Equity Ratio (DER) untuk menggambarkan proporsi total hutang terhadap ekuitas perusahaan. Berikut ini disajikan data Debt to Equity Ratio (DER) pada PT Unilever, Tbk yang terdaftar di Bursa Efek Indonesia periode 2009-2017 pada tabel 4:

Tabel 4. Debt to Equity Ratio pada PT

Unilever, Tbk yang terdaftar di Bursa Efek Indonesia Periode 2009-2017

\begin{tabular}{|c|c|c|c|}
\hline Tahun & $\begin{array}{c}\text { Total Hutang } \\
\text { (Rp) }\end{array}$ & $\begin{array}{c}\text { Total Ekuitas } \\
\text { (Rp) }\end{array}$ & $\begin{array}{c}\text { Debt } \\
\text { to } \\
\text { Equity } \\
\text { Ratio } \\
\text { (DER) } \\
\text { (Kali) }\end{array}$ \\
\hline 2009 & 3.776 .415 .000 .000 & 3.702 .819 .000 .000 & 1,02 \\
\hline 2010 & 4.652 .409 .000 .000 & 4.045 .419 .000 .000 & 1,15 \\
\hline 2011 & 6.801 .375 .000 .000 & 3.680 .937 .000 .000 & 1,85 \\
\hline 2012 & 8.016 .614 .000 .000 & 3.968 .365 .000 .000 & 2,02 \\
\hline 2013 & 9.093 .518 .000 .000 & 4.254 .670 .000 .000 & 2,14 \\
\hline 2014 & 9.681 .888 .000 .000 & 4.598 .782 .000 .000 & 2,11 \\
\hline 2015 & 10.902 .585 .000 .000 & 4.827 .360 .000 .000 & 2,26 \\
\hline 2016 & 12.041 .437 .000 .000 & 4.704 .258 .000 .000 & 2,56 \\
\hline 2017 & 13.733 .025 .000 .000 & 5.173 .388 .000 .000 & 2,65 \\
\hline \multicolumn{3}{|c|}{ Rata-Rata } & 1,97 \\
\hline \multicolumn{3}{|c|}{ Nilai Minimum } & 1,02 \\
\hline \multicolumn{3}{|c|}{ Nilai Maksimum } & 2,65 \\
\hline
\end{tabular}

Sumber: Laporan Keuangan PT Unilever, Tbk (Data Diolah, 2019)

Berdasarkan data tabel 4 di atas, ratarata Debt to Equity Ratio (DER) pada PT Unilever, Tbk yang terdaftar di Bursa Efek Indonesia periode 2009-2017 dapat juga disajikan dalam bentuk grafik yang dicantumkan pada Gambar 2 yakni sebagai berikut:

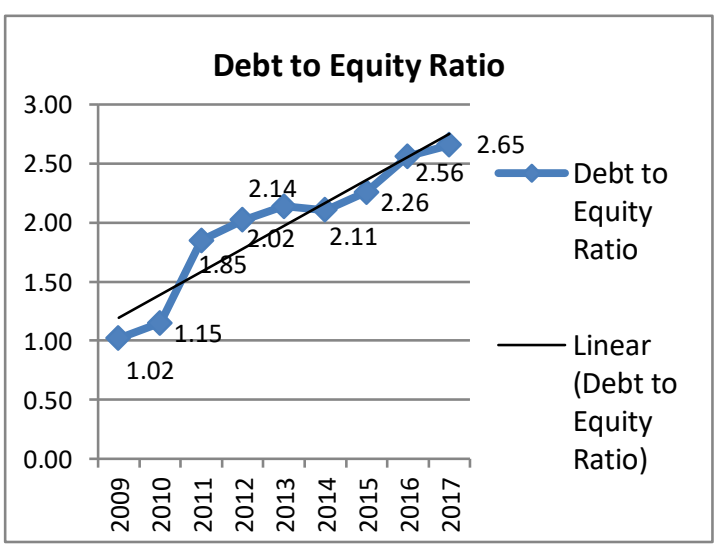

Sumber: Data Diolah (2019)

Gambar 2. Grafik Debt to Equity Ratio pada PT Unilever, Tbk yang terdaftar di Bursa Efek Indonesia periode 2009-2017 
Pada Tabel 4 dan Gambar 2 dapat dilihat bahwa nilai Debt to Equity Ratio (DER) pada PT Unilever, Tbk yang terdaftar di Bursa Efek Indonesia mengalami peningkatan walaupun pada tahun 2014 terjadi penurunan sebesar $0,03 \%$ dari tahun sebelumnya (2013) hal ini disebabkan karena penggunaan proporsi total hutang tidak begitu besar atau sebesar Rp.588.370.000.000 berbeda dengan tahun yang lainnya sedangkan proporsi total ekuitas mengalami sedikit peningkatan yakni sebesar Rp.344.112.000.000 berbeda dengan periode tahun lainnya. Nilai Debt to Equity Ratio (DER) minimum perusahaan periode 2009-2017 yakni sebesar 1,02 kali pada tahun 2009. Nilai Debt to Equity Ratio (DER) maksimum perusahaan periode 20092017 yakni sebesar 2,65 kali pada tahun 2017, yang disebabkan oleh peningkatan hutang jangka pendek dan hutang jangka panjang dengan proporsi $91,26 \%$ dan 8,74\%. Nilai rata-rata Debt to Equity Ratio (DER) perusahaan sebesar 1,97 kali. Artinya setiap Rp.1,00 ekuitas hanya menjamin hutang perusahaan sebesar Rp. 1,97. Debt to Equity Ratio (DER) yang memiliki nilai di atas rata berada pada tahun 2012-2017 sedangkan yang di bawah rata-rata berada pada tahun 2009-2011.

Gambaran Nilai Perusahaan pada PT Unilever, Tbk yang terdaftar di Bursa Efek Indonesia periode 2009-2017

Nilai Perusahaan merupakan gambaran cermin bagi investor untuk perusahaan yang mana dikaitkan dengan harga pasar saham. Harga pasar saham yang tinggi dan keuangan yang baik menunjukkan nilai perusahaan yang tinggi juga dan sebaliknya. Nilai perusahaan yang tinggi akan menarik perhatian para investor untuk berinvestasi. Dalam penelitian ini, penulis menggunakan Price to Earning Ratio (PER) untuk mengukur nilai perusahaan. Berikut ini disajikan Price to Earning Ratio (PER) pada PT Unilever, Tbk yang terdaftar di Bursa Efek Indonesia periode 2009-2017 pada tabel 5:

Tabel 5. Price to Earning Ratio pada PT Unilever, Tbk yang terdaftar di Bursa Efek Indonesia Periode 2009-2017

\begin{tabular}{|l|l|l|l|}
\hline Tahun & $\begin{array}{l}\text { Harga Pasar } \\
\text { Saham (Rp) }\end{array}$ & EPS (Rp) & $\begin{array}{l}\text { Price to } \\
\text { Earning Ratio } \\
\text { (PER) (Kali) }\end{array}$ \\
\hline 2009 & 11.050 & 399 & 27,69 \\
\hline 2010 & 16.500 & 444 & 37,16 \\
\hline 2011 & 18.800 & 546 & 34,43 \\
\hline 2012 & 20.850 & 634 & 32,89 \\
\hline 2013 & 26.000 & 701 & 37,09 \\
\hline 2014 & 32.300 & 752 & 42,95 \\
\hline 2015 & 37.000 & 766 & 48,30 \\
\hline 2016 & 38.800 & 838 & 46,30 \\
\hline 2017 & 55.900 & 918 & 60,89 \\
\hline Rata-Rata & 40,86 \\
\hline Nilai Minimum & 27,69 \\
\hline Nilai Maksimum & 60,89 \\
\hline
\end{tabular}

Sumber: Laporan Keuangan PT Unilever, Tbk (Data Diolah)

Berdasarkan Tabel 5 rata-rata Price to Earning Ratio (PER) pada PT Unilever, Tbk yang terdaftar di Bursa Efek Indonesia periode 2009-2017 juga dapat disajikan dalam bentuk grafik yakni sebagai berikut:

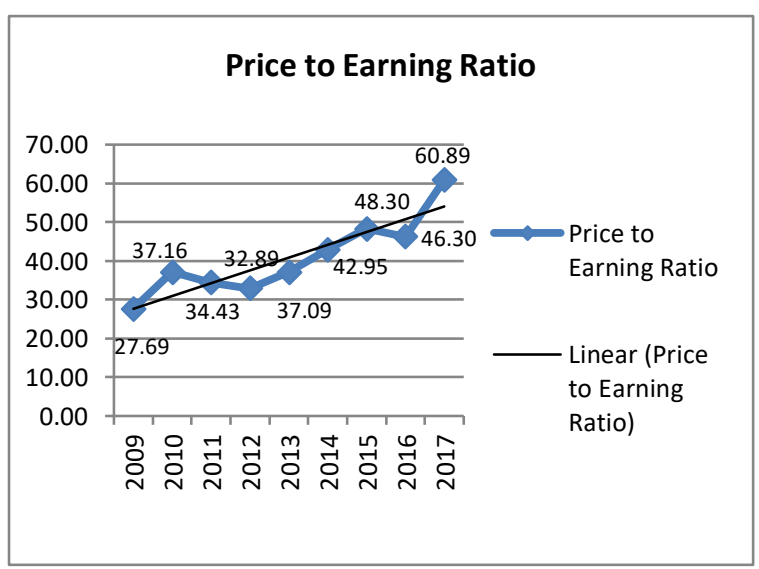

Sumber: Data Diolah (2019)

Gambar 3. Grafik Price to Earning Ratio pada PT Unilever, Tbk yang terdaftar di Bursa Efek Indonesia periode 2009-2017

Pada tabel 5 dan gambar 3 terlihat bahwa nilai Price to Earning Ratio (PER) pada PT Unilever, Tbk yang terdaftar di Bursa Efek Indonesia berfluktuasi dan mengalami peningkatan walaupun pada 
periode 2011-2012 mengalami penurunan. Hal ini diketahui nilai Price to Earning Ratio (PER) minimum perusahaan periode 2009-2017 adalah sebesar 27,69 kali pada tahun 2009. Hal ini disebabkan oleh harga pasar saham dan EPS yang rendah sedangkan nilai Price to Earning Ratio (PER) maksimum perusahaan periode 20092017 adalah sebesar 60,89 kali pada tahun 2017 dimana hal ini disebabkan karena adanya kenaikan harga pasar saham dari tahun ke tahun dan kenaikan harga Earning Per Share (EPS) dari tahun sebelumnya. Sedangkan nilai rata-rata Price to Earning Ratio (PER) perusahaan periode 2009-2017 adalah sebesar 40,86 kali. Nilai Price to Earning Ratio (PER) yang berada di atas nilai rata-rata terjadi pada tahun 2014 sampai 2017 dimana EPS mengalami peningkatan hingga mencapai kenaikan drastis pada tahun 2017 begitu juga dengan harga pasar saham yang mengalami kenaikan setiap tahunnya.

\section{Analisis Deskriptif Kuantitatif}

\section{Analisis Regresi Linier Sederhana}

Regresi Linear Sederhana digunakan untuk mengetahui ada atau tidak pengaruh likuiditas terhadap leverage dan pengaruh leverage terhadap nilai perusahaan. Pengujian analisis regresi linier sederhana dari likuiditas terhadap leverage pada penelitian ini menggunakan bantuan SPSS versi 21 yang disajikan pada tabel 6:

Tabel 6. Hasil Regresi Likuiditas Terhadap Leverage

\begin{tabular}{|c|c|c|c|}
\hline \multirow[t]{2}{*}{ Model } & \multicolumn{2}{|c|}{$\begin{array}{c}\text { Unstandardized } \\
\text { Coefficients }\end{array}$} & $\begin{array}{l}\text { Standardized } \\
\text { Coefficients }\end{array}$ \\
\hline & $\mathrm{B}$ & Std. Error & Beta \\
\hline (Constant) & 4.736 & .463 & \\
\hline CR & $-3,796$ & ,626 &,- 917 \\
\hline
\end{tabular}

Sumber: Hasil Pengolahan Data (2019)

Model persamaan regresi yang diperoleh adalah sebagai berikut: $Z=4,736-$ 3,796 X. Dari persamaan regresi di atas dapat diartikan bahwa likuiditas berpengaruh negatif terhadap leverage pada PT Unilever, Tbk yang terdaftar di Bursa Efek Indonesia periode 2009-2017. Pengujian analisis regresi linier sederhana dari leverage terhadap nilai perusahaan pada penelitian ini menggunakan bantuan SPSS versi 21 yang disajikan dalam Tabel 7:

Tabel 7. Hasil Regresi Leverage Terhadap Nilai Perusahaan

Coefficients $^{a}$

\begin{tabular}{|c|c|c|c|}
\hline \multirow[t]{2}{*}{ Model } & \multicolumn{2}{|c|}{$\begin{array}{c}\text { Unstandardized } \\
\text { Coefficients }\end{array}$} & $\begin{array}{l}\text { Standardized } \\
\text { Coefficients }\end{array}$ \\
\hline & B & Std. Error & Beta \\
\hline (Constant) & 13.952 & 8.753 & \\
\hline 1 DER & 13,633 & 4,284 & .769 \\
\hline
\end{tabular}

a. Dependent Variable: PER

Sumber: Hasil Pengolahan Data (2019)

Model persamaan regresi yang diperoleh adalah sebagai berikut: $\hat{Y}=13,952$ $+13,633$ Z. Dari persamaan regresi di atas dapat diartikan bahwa leverage berpengaruh positif terhadap nilai perusahaan pada PT Unilever, Tbk yang terdaftar di Bursa Efek Indonesia periode 2009-2017.

\section{Koefisien Korelasi dan Koefisien Determinasi}

Koefisien Korelasi bertujuan untuk mengetahui seberapa besar korelasi maupun hubungan antara variabel-variabel independen dengan variabel dependen. Sedangkan koefisien determinasi, menunjukkan kemampuan variabel independen menjelaskan variasi perubahan pada variabel dependen. Hasil analisis koefisien korelasi dan koefisien determinasi dari hubungan likuiditas dengan leverage adalah sebagai berikut:

Tabel 8. Hasil Analisis Korelasi dan Koefisien Determinasi

\begin{tabular}{l|r|r|r|r|}
\hline Model & $\mathbf{R}$ & $\begin{array}{c}\mathbf{R} \\
\text { Square }\end{array}$ & $\begin{array}{c}\text { Adjusted R } \\
\text { Square }\end{array}$ & $\begin{array}{l}\text { Std. Error of the } \\
\text { Estimate }\end{array}$ \\
\hline $\mathbf{1}$ & $\mathbf{. 9 1 7}$ & $\mathbf{. 8 4 0}$ & .817 & 24.062 \\
\hline
\end{tabular}

Sumber: Hasil Pengolahan Data (2019) 
Dari tabel diatas nilai korelasi sebesar 0,917 yang artinya terdapat hubungan yang sangat kuat antara likuiditas dengan leverage pada PT Unilever, Tbk yang terdaftar di Bursa Efek Indonesia periode 2009-2017. Selanjutnya, diperoleh koefisien determinasi sebesar 0,840 yang artinya tinggi rendahnya leverage sebesar $84,0 \%$ dapat dijelaskan oleh variabel likuiditas sedangkan sisanya $16,0 \%$ dapat dijelaskan oleh variabel lain yang tidak dibahas dalam penelitian ini, seperti profitabilitas, struktur aset, stabilitas penjualan dan lain-lain.

Tabel 9. Hasil Analisis Korelasi dan Koefisien Determinasi Model Summary ${ }^{b}$

\begin{tabular}{|l|r|r|r|r|}
\hline Model & $\mathbf{R}$ & $\begin{array}{c}\text { R } \\
\text { Square }\end{array}$ & $\begin{array}{c}\text { Adjusted R } \\
\text { Square }\end{array}$ & $\begin{array}{c}\text { Std. Error of the } \\
\text { Estimate }\end{array}$ \\
\hline $\mathbf{1}$ &. $\mathbf{7 6 9}$ & $\mathbf{. 5 9 1}$ & .533 & 68.2002 \\
\hline
\end{tabular}
a. Predictors: (Constant), DER
b. Dependent Variable: PER

Sumber: Hasil Pengolahan Data (2019)

Dari Tabel diatas nilai korelasi sebesar 0,769 yang artinya terdapat hubungan yang kuat antara leverage dengan nilai perusahaan. Kemudian, diperoleh koefisien determinasi sebesar 0,591 yang artinya tinggi rendahnya leverage sebesar 59,1\% dapat dijelaskan oleh variabel leverage sedangkan sisanya sebesar $40,9 \%$ dapat dijelaskan oleh variabel lain yang tidak dibahas dalam penelitian ini, seperti keputusan investasi, kebijakan dividen manajemen aset, dan lainnya.

\section{Uji Hipotesis}

Uji hipotesis 1 menggunakan uji t untuk mengetahui apakah antar variabel bebas (likuiditas) dan variabel intervening (leverage) memiliki hubungan yang signifikan atau tidak. Jika thitung $>$ ttabel atau signifikansi $\leq 0,05$, maka $\mathrm{H} 0$ ditolak.Pengujian uji $\mathrm{t}$ likuiditas terhadap leverage disajikan pada table dibawah ini.
Tabel 10 Hasil thitung

\begin{tabular}{|c|c|c|}
\hline \multicolumn{3}{|c|}{ Coefficients $^{\boldsymbol{a}}$} \\
\hline Model & $\mathrm{t}$ & $\mathrm{Sig}$ \\
\hline Constant & 10.239 & \\
\hline CR & $\mathbf{- 6 . 0 6 5}$ & $\mathbf{0 . 0 0 0}$ \\
\hline
\end{tabular}

Sumber: hasil pengolahan data (2019)

Dari tabel dapat dilihat bahwa Current Ratio (CR) memiliki nilai thitung sebesar 6,065 , sedangkan ttabel dengan $\mathrm{df}=\mathrm{n}-2(9$ - 2 =7) sebesar 2,364 atau dengan taraf signifikan $0,001<\alpha 0,05$ maka H0 ditolak, yang artinya Likuiditas berpengaruh negatif signifikan terhadap Leverage pada PT Unilever, Tbk yang terdaftar di Bursa Efek Indonesia periode 2009-2017. Pengujian selanjutnya adalah uji $\mathrm{t}$ antara leverage terhadap nilai perusahaan. Uji hipotesis 2 menggunakan uji $\mathrm{t}$ untuk mengetahui apakah antar variabel intervening (leverage) dan variabel terikat (nilai perusahaan) memiliki hubungan yang signifikan atau tidak. Jika thitung $>$ ttabel atau signifikansi $\leq 0,05$, maka H0 ditolak.

Tabel 11. Hasil $\mathbf{t}_{\text {hitung }}$

\begin{tabular}{|c|c|c|}
\hline \multicolumn{3}{|c|}{ Coefficients $^{\boldsymbol{a}}$} \\
\hline Model & $\mathrm{t}$ & Sig \\
\hline Constant & 1.594 & \\
\hline DER & $\mathbf{3 . 1 8 3}$ & $\mathbf{0 . 0 1 5}$ \\
\hline
\end{tabular}

Sumber: hasil pengujian dari SPSS Statistics versi 21 (2019)

Pada tabel diatas diperoleh nilai thitung sebesar 3,183 sedangkan untuk ttabel dengan $\mathrm{df}=\mathrm{n}-2(9-2=7)$ sebesar 2,364 atau dengan taraf signifikan $0,015<\alpha 0,05$ maka H0 ditolak, artinya Leverage berpengaruh positif signifikan terhadap Nilai Perusahaan pada PT Unilever, Tbk yang terdaftar di Bursa Efek Indonesia periode 2009-2017.

\section{Evaluasi}

\section{Likuiditas pada PT Unilever, Tbk yang Terdaftar di Bursa Efek Indonesia}

Untuk melunasi hutang perusahaan sebaiknya perusahaan mengendalikan aset lancar dengan baik dan memanfaatkan untuk 
kegiatan investasi guna menambah laba perusahaan, contohnya kas dan setara kas. Perusahaan perlu melakukan penagihan piutang usaha guna untuk mendapatkan penambahan dana kas dan membatasi persediaan yang terlalu besar karena memerlukan biaya tambahan dan dapat mengurangi pendapatan laba. Pengendalian terhadap aset lancar dapat mengurangi sebagian dana yang tidak produktif sehingga nilai leverage akan optimal. Current Ratio (CR) yang memiliki nilai di bawah rata-rata berada pada tahun 2011-2017.Rendahnya nilai Current Ratio (CR) terjadi karena peningkatan jumlah proporsi hutang lancar lebih besar dibandingkan aset lancarnya. Nilai Current Ratio (CR) minimum terjadi pada tahun 2016 yakni 0,61 kali, dimana terjadi peningkatan hutang lancar dari tahun 2015 ke tahun 2016 sebesar Rp. 750.532.000.000 sedangkan aset lancar mengalami penurunan sebesar Rp.35.005.000.000.

Leverage pada PT Unilever, Tbk yang terdaftar di Bursa Efek Indonesia

Dari hasil penelitian, penulis menunjukkan kondisi Leverage yang diukur dengan parameter Debt to Equity Ratio (DER) perusahaan cenderung mengalami kenaikan walaupun pada tahun 2014 terjadi penurunan sebesar $0,03 \%$ dari tahun sebelumnya. Rata-rata nilai Debt to Equity Ratio (DER) pada PT Unilever, Tbk periode 2009-2017 sebesar 1,97. Hal ini menunjukkan rata-rata keseluruhan perbandingan antara total hutang dengan ekuitas sebesar 1,97 kali. Debt to Equity Ratio (DER) yang memiliki nilai di atas rata-rata berada pada tahun 2012 sampai 2017 hal ini disebabkan karena peningkatan hutang dalam jumlah yang lumayan besar dibandingkan dengan peningkatan total ekuitas yang tidak begitu besar tingkat pertambahannya. Sedangkan Debt to Equity Ratio yang memiliki nilai di bawah rata-rata berada pada tahun 2009-2011.

\section{Nilai Perusahaan pada PT Unilever, Tbk yang terdaftar di Bursa Efek Indonesia}

Dari hasil penelitian penulis menunjukkan kondisi nilai perusahaan yang diukur dengan parameter Price to Earning Ratio (PER) mengalami fluktuasi dan cenderung meningkat sama halnya dengan harga pasar saham dan EPS yang meningkat setiap tahunnya. Rata - rata nilai Price to Earning Ratio (PER) pada PT Unilever, Tbk periode 2009-2017 yakni sebesar 40,46 kali. Hal ini menunjukkan bahwa rata-rata perbandingan harga pasar saham dengan EPS sebesar 40,46 kali. Nilai Price to Earning Ratio (PER) yang berada di atas rata-rata terjadi pada tahun 2014 sampai 2017 dimana EPS mengalami peningkatan hingga mencapai kenaikan yang drastis pada tahun 2017 begitu juga dengan harga pasar saham yang ikut mengalami kenaikan dari tahun sebelumnya. Sedangkan nilai Price to Earning Ratio (PER) yang berada di bawah rata-rata terjadi pada tahun 2009-2013 dengan harga pasar saham dan EPS yang meningkat dari tahun ke tahun hanya saja nilai PER mengalami penurunan pada tahun 2011-2012. Nilai Price to Earning Ratio (PER) minimum terjadi pada tahun 2009 yakni sebesar 27,69 kali.

\section{KESIMPULAN DAN SARAN}

\section{Kesimpulan}

Dari hasil pengujian regresi linier sederhana diketahui bahwa leverage berpengaruh positif signifikan terhadap nilai perusahaan pada PT Unilever, Tbk yang terdaftar di Bursa Efek Indonesia periode 2009-2017. Dari hasil uji koefisien korelasi dan koefisien determinasi likuiditas terhadap leverage diketahui terdapat hubungan yang sangat kuat dan positif antara likuiditas (X) 
terhadap leverage $(\mathrm{Z})$ dan leverage lebih banyak dipengaruhi oleh Likuiditas. Dari hasil uji koefisien korelasi dan koefisien determinasi leverage terhadap nilai perusahaan diketahui terdapat hubungan yang kuat dan positif antara leverage (Z) terhadap nilai perusahaan (Y) dan nilai perusahaan lebih banyak dipengaruhi oleh leverage. Dari hasil uji koefisien korelasi dan koefisien determinasi leverage tidak bisa menjadi variabel intervening bagi likuiditas terhadap nilai perusahaan dikarenakan nilai korelasi untuk likuiditas (X) terhadap leverage (Z) lebih besar dibandingkan leverage $(\mathrm{Z})$ terhadap nilai perusahaan (Y). Hasil pengujian hipotesis pertama dapat diketahui bahwa likuiditas berpengaruh negatif signifikan terhadap leverage pada PT Unilever, Tbk yang terdaftar di Bursa Efek Indonesia periode 2009-2017. Hasil pengujian hipotesis kedua dapat diketahui bahwa leverage berpengaruh positif signifikan terhadap nilai perusahaan pada PT Unilever, Tbk yang terdaftar di Bursa Efek Indonesia periode 2009-2017.

\section{Saran}

Untuk likuiditas perusahaan, sebaiknya perusahaan melakukan pengelolaan dan pengendalian aset lancar agar tidak terjadi adanya saldo kas yang menganggur, penumpukan persediaan barang serta kebijakan kredit perusahaan yang tidak baik sehingga mengakibatkan tingginya piutang usaha. Hal ini akan membuat nilai likuiditas semakin tinggi yang berpengaruh kepada kemampuan laba perusahaan sehingga leverage perusahaan tidak optimal. Untuk leverage perusahaan, perusahaan bisa tetap mempertahankan dalam penggunaan proporsi hutang dibandingkan ekuitas perusahaan dimana modal hutang yang digunakan sebagai dana untuk meningkatkan penjualan sehingga menghasilkan laba. Akan tetapi perusahaan juga harus memperhatikan keadaan internal dan eksternal perusahaan hal ini dikarenakan penggunaan hutang terlalu tinggi akan dikhawatirkan dalam pembayaran biaya bunga yang tinggi pula ditambah keadaan ekonomi yang terjadi misalnya inflasi yang menyebabkan resesi ekonomi sehingga perusahaan akan kesulitan dalam membayar hutangnya. Untuk meningkatkan nilai perusahaan alangkah bagusnya perusahaan melakukan pengendalian yang baik terhadap manajemen aset, manajemen hutang dan ekuitas agar profit bisa meningkat sehingga secara otomatis akan meningkatkan nilai perusahaan yang berimplikasi terhadap kepercayaan yang positif bagi investor.

\section{DAFTAR PUSTAKA}

Brigham, Eugene F, dan Joel Houston 2001. Dasar-Dasar Manajemen Keuangan. Buku I, Edisi XI. Jakarta: Salemba Empat.

Hasibuan, Veronica, Moch Dzulkirom AR, Endang NP. 2016. Pengaruh Leverage dan Profitabilitas Terhadap Nilai Perusahaan (Studi Pada Perusahaan Property Estate yang Terdaftar di Bursa Efek Indonesia Periode 2012-2015). Jurnal Adminitrasi Bisnis. 39 (1), 139-147.

Kasmir. 2010. Pengantar Manajemen

Keuangan. Edisi Pertama. Cetakan Kedua. Jakarta: Pranada Group.

Keown, et.al.2004. Manajemen Keuangan: Prinsip-prinsip Dasar dan Aplikasi. Edisi Kesembilan. Jilid 1.Jakarta Indeks kelompok Gramedia.

Ramadhani, Ridho, Akhmadi dan Kuswantoro. (2018). Pengaruh Leverage dan Profitabilitas Terhadap Nilai Perusahaan Dengan Kebijakan Dividen Sebagai Variabel 
Intervening. Jurnal Riset Bisnis dan Manajemen Tirtayasa (JRBMT). 2 (1), 21-42.

Robbins, Stephen dan Mary Coulter. 2010. Manajemen. Jakarta: PT. Indeks.

Rudangga, I Gusti Ngurah Gede dan Gede

Merta Sudiarta. 2016. Pengaruh

Ukuran Perusahaan, Leverage dan

Profitabilitas Terhadap Nilai

Perusahaan. E-Jurnal Manajemen

Unud. 5 (7), 4394-4422.

Sambora, Mareta Nurjin, Siti Ragil Handayani dan Sri Mangesti Rahayu. 2014. Pengaruh Leverage dan Profitabilitas Terhadap Nilai Perusahaan (Studi Pada Perusahaan Food dan Beverages yang Terdaftar di BEI Periode tahun 2009-2012). Jurnal Adminitrasi Bisnis. 8 (1), 110.

Sholekah, Febrina Wibawati dan Lintang Venusita. 2014. Pengaruh Kepemilikan Manajerial, Kepemilikan Institusional, Leverage, Firm Size dan Corporate Social Responsibility Terhadap Nilai Perusahaan Pada Perusahaan High Profile yang Terdaftar di Bursa Efek Indonesia Periode Tahun 20082012. Jurnal Ilmu Manajemen. 2 (3), 795-807.

Solikahan, Eka Zahra, Kusuma Ratnawati dan Achmad Helmy Djawahir. 2013. Pengaruh Leverage dan Investasi Terhadap Nilai Perusahaan (Studi Pada Perusahaan Makanan dan Minuman di Bursa Efek Indonesia). Jurnal Aplikasi Manajemen. 2 (3), 427-433.

Sudana, I Made. 2011. Manajemen

Keuangan Perusahaan: Teori dan

Praktik. Jakarta: Erlangga.

Suwardika, I Nyoman Agus dan I Ketut Mustanda. 2017. Pengaruh Leverage,
Ukuran Perusahaan, Pertumbuhan Perusahaan dan Profitabilitas Terhadap Nilai Perusahaan Pada Perusahaan Properti. E-Jurnal Manajemen Unud. 6 (3), 1248-1277. Widjaja, Indra. 2014. Dampak Peningkatan Asset, Profitabilitas dan Likuiditas Terhadap Leverage Perusahaan. Jurnal Akuntansi. 18 (3), 459-474.

\section{Profil Singkat}

Jody Styawan, Lahir di Pematangsiantar, tanggal 09 Mei 1997, lulus dari jurusan Sarjana Manajemen Sekolah Tinggi Ilmu Ekonomi Sultan Agung pada tahun 2019. Robert Tua Siregar, gelar magister Sains diperoleh dari Universitas Sumatera Utara dan lulus pada tahun 2001. Gelar doktor diperoleh dari Universitas Malaya Malaysia dan lulus pada tahun 2011. Sherly, gelar magister manajemen diperoleh dari Program Magister Manajemen Fakultas Pascasarjana Universitas HKBP Nommensen Medan dan lulus pada tahun 2015. Novita Butarbutar, gelar magister manajemen diperoleh dari Program Magister Manajemen Fakultas Pascasarjana Universitas HKBP Nommensen Medan dan lulus pada tahun 2017. 